\title{
Sports Facilities and Social Responsibility: A Challenge for the Decade
}

\author{
Susana Lucas ${ }^{1, *}$, Boguslawa Sardinha ${ }^{2, *}$ \\ 1 Susana Maria Melo Fernandes Afonso Lucas / Escola Superior de Tecnologia do Barreiro do \\ Instituto Politécnico de Setúbal - Lavradio, Portugal \\ 2 Boguslawa Sardinha / SOCIUS - Research Centre in Economics and Organizational Sociology, \\ Department of Economics and Management, Polytechnic Institute of Setubal, Portugal
}

E-Mails: susana.lucas@estbarreiro.ips.pt; boguslawa.sardinha@esce.ips.pt

\begin{abstract}
* Author to whom correspondence should be addressed; Tel.: +351- 212- 064- 660; Fax: +351- 212075- 002
\end{abstract}

Received: / Accepted: / Published:

\footnotetext{
Abstract: The last decade of the XX century consolidated a new vision of development that involved not only the natural environment, but also socio-cultural aspects in a prominent position, argued that the quality of life of human beings became the condition for progress. This proposal is based on sustainable development considering the preservation for future generation's current use of natural resources. We cannot imagine the functioning of the developed societies without major hospitals, shopping malls, sports facilities, public transport stations, public institutions, schools, waste treatment plants etc.. The construction of such equipment involves huge amounts of money and produces a significant impact on the neighbourhood. These impacts on the economy, called externalities, can be positive or negative. Looking at the issue of community facilities from a macroeconomic point of view, a proper functioning of such equipment is essential for the development of local communities and general society. Amidst the global crisis, the best and most profitable use of such equipment
} 
enhances its positive impacts on society, which is supposed to be inclusive, and creates the structural conditions for social and economic growth. Many of those items can be better managed taking into consideration social sustainability by creating conditions for local and country development. A more inclusive and participatory society is one of the key objectives of Europe 2020. The EU commission has identified three elements for the growth of the European state in the coming years: smart growth, sustainable growth (making our production more efficient in terms of resources, while boosting our competitiveness), inclusive growth (increased rate of participation in the labour market, acquiring skills and the fighting poverty). For the success of this strategy for the next decade, it is essential to have a social vision of the market. Improved management of such equipment can create opportunities for civic engagement of local citizens, for education and even for the creation of micro-business around the equipment. The greater involvement of citizens also allows channelling the energies of many social groups to make the social goals comprehensive, providing the appearance of a more participatory society. Companies today face many management problems of social sustainability in its various dimensions such as: demographic changes, social justice, education, health, among others. The proper management approach has to be an answer on how to deal with these problems. The objective of our work is the introductory analyses of the state of art of the management for social sustainability objectives of the sports facilities in Portugal. After this introductory analysis, we will propose the creation of a methodological guide for managers of these public facilities, in order to include the social sustainability aspects on their task and management objectives.

Keywords: Management, social sustainability; sport facilities.

\section{Introduction}

During many years in sustainable development research the three dimensions the sustainability have not been equally prioritized. Since In early 1980s till mid 1990 the environmental dimension dominated in the sustainable research approach. After that time, environmental and economic approach gained the same importance in the studies. Only in the beginning of this centaury the social dimension of sustainable approach amplified it importance and now it is common sense that those entire three dimension have the same importance in the research. What is the social sustainability?

Sachs (1999) defined it as "the social preconditions for sustainable development or the need to sustain specific structures and customers in communities and societies”. Litting and Giessler (2005) "argue that approaches to the social sustainability concept have not been grounded on theory but rather on a practical understanding of plausibility and current political agendas.” (cross Colantonio 2006)

Different approach presented Assefa and Frostell (2007), who indicated that social sustainability is the finality of development at the same time as economic and environmental sustainability are both the goals of sustainable development and instrument to its achievements. 
Chiu (2003) identifies three main approaches to the social sustainability interpretation. In the first perspectives, social sustainability equates as environmental sustainability, she affirmed that "social sustainability of an activity depends upon specific relations, customs, structure and value, representing the social limit and constrains of development" Colantionio (2009). The second approach, environmental oriented, indicated that "social structure, values and norms can be changed in order to carry out activities within the physical limits of the planet " and finally the third approach , people oriented , indicated that then improving the wellbeing of people and the equitable distribution of recourses at the same time as reduces social exclusion and destructive conflicts.

The management of sports facilities, especially football stadiums, present a high complexity and diversity and it is a very interesting case study for analysis of social sustainability. Stages are dynamic events that millions of people for the same purpose and create ties social very narrow.

Europe 2020 set guidelines for growth in Europe. In these guidelines the components and Social Sustainability is largely focused, planned and potential for boosting wealth.

The objective of this paper to present the preliminary approach of Social Sustainability issues in management of football stadiums

\subsection{Social sustainability assessment}

For adequate social sustainability assessment it's very important to define set of indicators.

In 2000, the International Institute for Sustainable Development, (IISD) offered the following guide to useful criteria for judging the value of a given indicator:

- Policy relevance

- Simplicity

- Validity

- Time-series data

- Availability of affordable data

- Ability to aggregate information

- Sensitivity

- Reliability

During some years many different organizations have endeavoured to develop sets of indicators with respect to sustainability objectives. At the beginning, different sets of indicators cover specific aspects of social sustainability although it can be argued that older indexes priorities the basic needs component. More recently developed indicators emphasize the importance of governance, representation and institutional factors.

The next step is to index the elements taken into account and weighted together with other dimensions of sustainable development in an attempt to deliver an integrated approach to sustainability.

Considering the IISD advises and lack of any available data we decided to use more traditional approach for social sustainability. We also adopted the indications to the reality of management of stadium in Portugal. We also had done twofold analyses private management and public interest.

For our first approach to the theme we study the following social impact in management of Portuguese stadiums; 
- neighbourhood;

- education;

- economic opportunity;

- interaction and participation;

- well being

Figure $\mathbf{n}^{\mathbf{0}} \mathbf{1}$ - The model of social sustainability approach

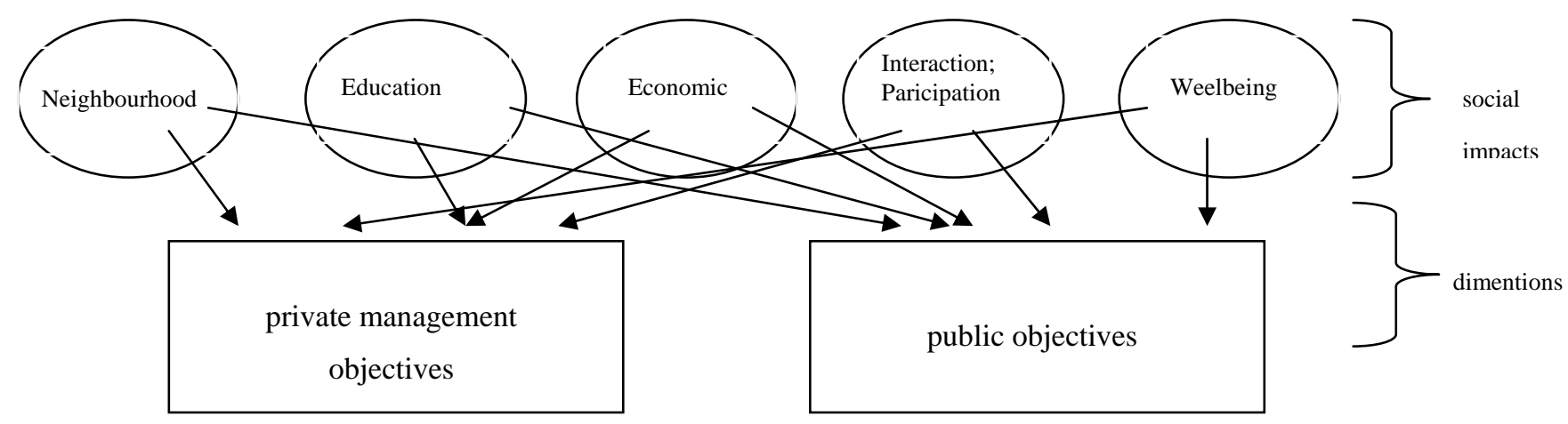

Source: Authors construction

The other challenge was to find the adequate method of assents. Considering the number of existent assessment methods (table 1) we decided to use for this primarily approach the community assessment evaluation with participation of the members of management board of the most important stadiums in Portugal.

Table $\mathbf{n}^{\mathbf{0}} \mathbf{1}$ - Assessment methods for social sustainability

\begin{tabular}{|c|c|c|}
\hline Method & Main use of the method & Stakeholders \\
\hline $\begin{array}{l}\text { Analysis of Interconnected } \\
\text { Decision Areas (AIDA) }\end{array}$ & $\begin{array}{l}\text { Aiding informed } \\
\text { choices }\end{array}$ & $\begin{array}{l}\text { Policy makers, project } \\
\text { managers, planners, } \\
\text { experts. }\end{array}$ \\
\hline $\begin{array}{l}\text { Analytic Hierarchy Process } \\
\text { (AHP) }\end{array}$ & $\begin{array}{l}\text { Aiding informed choices } \\
\text { based } \\
\text { on a set of criteria }\end{array}$ & $\begin{array}{l}\text { Policy makers and } \\
\text { planners, to lesser extent } \\
\text { also private investors and } \\
\text { service providers }\end{array}$ \\
\hline $\begin{array}{l}\text { Availability of Public, } \\
\text { Near-Residential } \\
\text { Spaces }\end{array}$ & $\begin{array}{l}\text { Collecting and initial } \\
\text { analysis } \\
\text { of data }\end{array}$ & $\begin{array}{l}\text { Planners, administrators, } \\
\text { managers, consultants }\end{array}$ \\
\hline Brainstorming & $\begin{array}{l}\text { Exploring the } \\
\text { future }\end{array}$ & All \\
\hline Cluster Analysis & $\begin{array}{l}\text { Initial analysis } \\
\text { of data }\end{array}$ & $\begin{array}{l}\text { Complex method, mainly } \\
\text { for planners, consultants, } \\
\text { research } \\
\text { institutes }\end{array}$ \\
\hline $\begin{array}{l}\text { Community } \\
\text { Evaluation }\end{array}$ & $\begin{array}{l}\text { Assessment and evaluation } \\
\text { of impacts }\end{array}$ & $\begin{array}{l}\text { Experts (architects, } \\
\text { planners, surveyors) in } \\
\text { consultation with } \\
\text { representatives of the } \\
\text { community and businesses }\end{array}$ \\
\hline Concordance Analysis & Aiding informed choices & Mainly planners \\
\hline
\end{tabular}


based

on a set of criteria

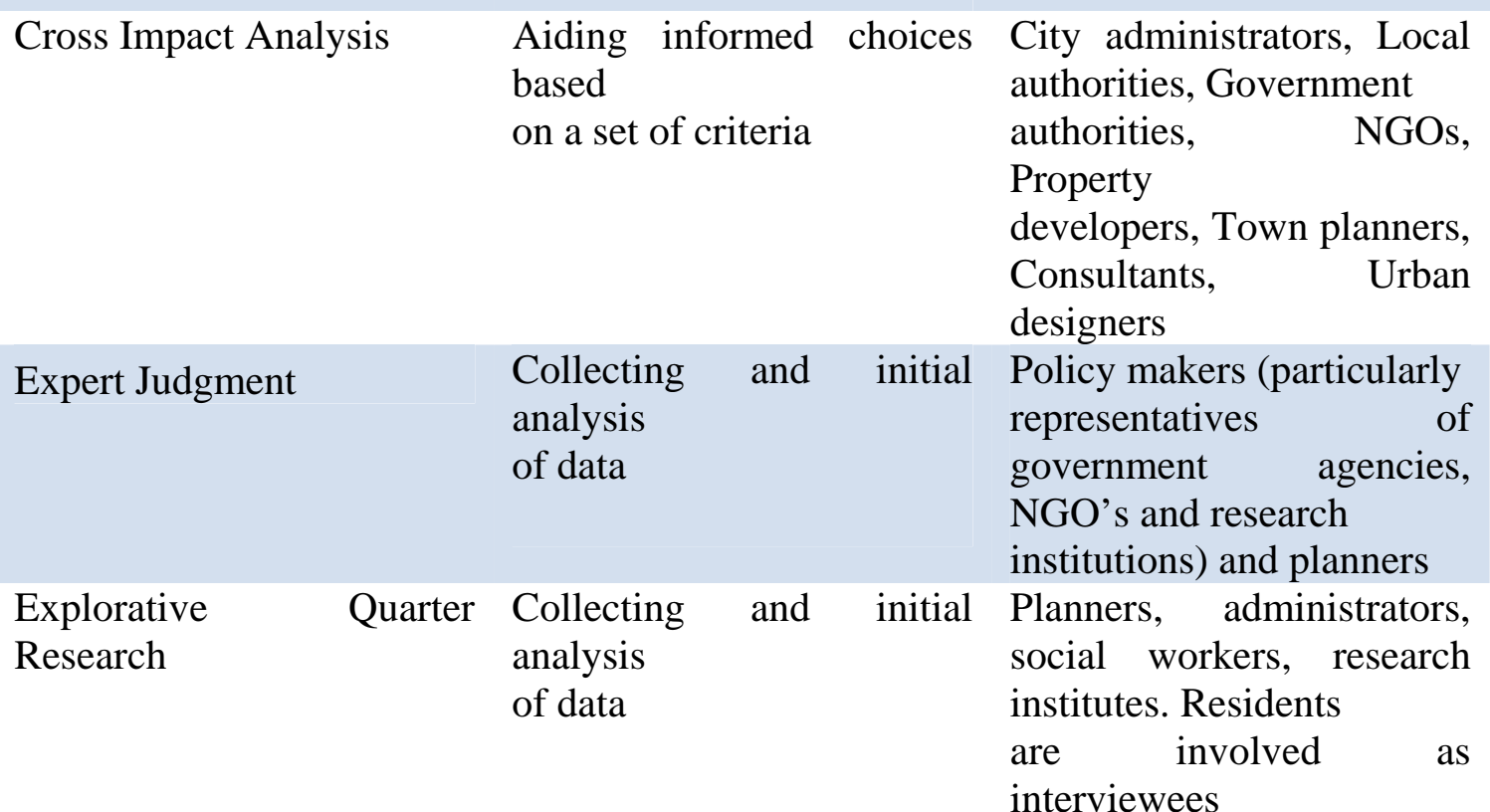

\begin{tabular}{ll} 
Focus Groups & Exploring the future \\
\hline Flag Model & $\begin{array}{l}\text { Aiding informed choices } \\
\text { based on a set of } \\
\text { criteria }\end{array}$
\end{tabular}

\section{All}

Planners and other

Experts. Inclusion of other stakeholders' interests through the definition of pre-defined indicators and benchmark values

\begin{tabular}{|c|c|c|}
\hline Futures Workshops & Exploring the future & All \\
\hline Horizon Scanning & Exploring the future & $\begin{array}{l}\text { Governments agencies, } \\
\text { NGO's, } \\
\text { institutions and planning } \\
\text { consultants }\end{array}$ \\
\hline $\begin{array}{l}\text { Managing Speeds of } \\
\text { Traffic on European } \\
\text { Roads (MASTER }\end{array}$ & $\begin{array}{l}\text { Collecting and initial } \\
\text { analysis } \\
\text { of data }\end{array}$ & $\begin{array}{l}\text { City administrators, Local } \\
\text { authorities, Government } \\
\text { agencies, Research } \\
\text { institutions, } \\
\text { planners, Urban designers, } \\
\text { Consultants, Building and } \\
\text { infrastructure } \\
\begin{array}{l}\text { owners, Transport and } \\
\text { utility } \\
\text { service providers }\end{array}\end{array}$ \\
\hline $\begin{array}{l}\text { Multi-Criteria } \\
\text { Analysis (MCA) }\end{array}$ & $\begin{array}{l}\text { Aiding informed choices } \\
\text { based } \\
\text { on a set of criteria }\end{array}$ & $\begin{array}{l}\text { Planners and local } \\
\text { stakeholders, such as } \\
\text { citizens and members } \\
\text { of the business community }\end{array}$ \\
\hline Quality of Life Assessment & $\begin{array}{l}\text { Collecting and initial } \\
\text { analysis of data }\end{array}$ & All, but especially citizens \\
\hline Risk Assessment & Assessment and evaluation & Planners, managers, service \\
\hline
\end{tabular}




\begin{tabular}{|c|c|c|}
\hline & of impacts & $\begin{array}{l}\text { providers (health and } \\
\text { safety officers), policy } \\
\text { makers and } \\
\text { private investors }\end{array}$ \\
\hline $\begin{array}{l}\text { Scenario } \\
\text { Development }\end{array}$ & Exploring the future & $\begin{array}{l}\text { Civic service, private } \\
\text { enterprise, planning, } \\
\text { operational and citizens }\end{array}$ \\
\hline Semantic Differential & $\begin{array}{l}\text { Collecting and } \\
\text { initial analysis } \\
\text { of data }\end{array}$ & $\begin{array}{l}\text { municipal authorities, } \\
\text { citizens, designers, } \\
\text { planners, consultants, } \\
\text { researches }\end{array}$ \\
\hline Cost-Benefit & $\begin{array}{l}\text { Assessment and evaluation } \\
\text { of impacts }\end{array}$ & $\begin{array}{l}\text { Planners carry out the } \\
\text { assessment. Political } \\
\text { representatives, citizens } \\
\text { and members of the } \\
\text { business community aid } \\
\text { decision-making } \\
\text { Building to regional } \\
\text { Medium to } \\
\text { Long-term. }\end{array}$ \\
\hline $\begin{array}{l}\text { Social Impact } \\
\text { Assessment }\end{array}$ & $\begin{array}{l}\text { Assessment and evaluation } \\
\text { of impacts }\end{array}$ & $\begin{array}{l}\text { Planners and policy } \\
\text { makers, private investors, } \\
\text { service providers and } \\
\text { public }\end{array}$ \\
\hline Spider Analysis & $\begin{array}{l}\text { Aiding informed } \\
\text { choices based } \\
\text { on a set of } \\
\text { criteria }\end{array}$ & $\begin{array}{l}\text { Policy makers, planners, } \\
\text { service providers, property } \\
\text { developers, citizens }\end{array}$ \\
\hline $\begin{array}{l}\text { Strategic } \\
\text { Conversations }\end{array}$ & $\begin{array}{l}\text { Exploring the } \\
\text { future }\end{array}$ & $\begin{array}{l}\text { Government agencies, } \\
\text { NGO's research institutes, } \\
\text { private } \\
\text { investors, planners }\end{array}$ \\
\hline $\begin{array}{l}\text { Survey } \\
\text { Questionnaires }\end{array}$ & $\begin{array}{l}\text { Collecting and } \\
\text { initial analysis } \\
\text { of data }\end{array}$ & $\begin{array}{l}\text { Governments, civic } \\
\text { services, planners } \\
\text { commercial } \\
\text { organizations, private } \\
\text { investors citizens }\end{array}$ \\
\hline SWOT Analysis & $\begin{array}{l}\text { Exploring the } \\
\text { future }\end{array}$ & $\begin{array}{l}\text { Public bodies (policy } \\
\text { makers), planners and } \\
\text { private investors }\end{array}$ \\
\hline Visioning & $\begin{array}{l}\text { Exploring the } \\
\text { future }\end{array}$ & $\begin{array}{l}\text { Policy makers, private } \\
\text { investors, planners, service } \\
\text { providers or citizens }\end{array}$ \\
\hline Wind Tunnel Testing & $\begin{array}{l}\text { Exploring the } \\
\text { future }\end{array}$ & $\begin{array}{l}\text { Policy makers, private } \\
\text { investors, planners, service } \\
\text { providers, citizens }\end{array}$ \\
\hline
\end{tabular}




\section{Method}

We developed two analysis engines that were available at a Workshop held in October 2011 at the Portuguese Association Stadium. In this event were represented six Portuguese stadiums: the Benfica stadium (where the event took place), Sporting Stadium, stadium of the Dragon, Stadium of Aveiro, Leiria Stadium and the Algarve Stadium.

In a survey on the Social Sustainability indicators have been defined and several representatives of each stage had to indicate positive, negative, and suggestions for improvements. This survey was answered by the representatives of each stage separately.

Defined in terms of indicators were defined: the neighborhood, safety, sense of pride, educational opportunity, responding to local needs, local economic stimulation, equal access, social inclusion, traffic and parking, and finally the assessment of impacts.

Another source of information was PBL (Problem Based Learning) activity results. During this activity we presented the real problems related with stadium management.

Using those two different methods allowed us to collect the twofold information. First the real stat of social sustainability issues management and second the stadium managers awareness considering the social sustainability issues.

Taking into account limited number of participators we decided to present five problems connected to some social sustainability dimensions such as: neighborhood disturbances; educational opportunities, economic opportunities, social interaction mechanism problem and well being of the sport facility customers. The objective to present those issues was to complete the initial inquiry with some most problematic subjects to deal with in sport facilities management.

During PBL activity the stadium managers were divided into mixed groups of two or three elements and discussed real problems. The first problem was related with the fan disturbs on neighborhood causing trash, noise, traffic jam. Group members have to present the solution for this real problem. The second group was invited to present the creative solution for the education and social inclusion opportunities in sport facility management. The third group discussed the economic neighborhood dynamic and creation opportunity for small business development. The fourth group discussed how to increase the social interaction and feedback in order to minimize the negative influence of the sport facilities for the surroundings, and finally the last group discussed problem of wellbeing, comfort and security of the stadium clients.

\section{Results and Discussion}

Our first challenge was to present that the social sustainability dimensions are fundamental and complementary for the economic sustainability / survival of their sport equipment.

For the survey of Social Responsibility, which was answered by each management team of a football stadium, we obtained the following results in relation to indicators. The results are then presented in a systematic and consolidation of individual information of each stage, presenting the themes referenced. 
For indicator neighborhood in positive terms there is the highlight partnerships with public and private institutions, offering multisport and improvement of the surrounding area. In terms of negative noise has been widely presented as well as congestion on game days, the high consumption of the structure and lack of integration of the structure with its surroundings were also presented. Were proposed some improvements the promotion of public transport, development of mechanisms of interaction with the population and better functioning of the existing space in the structure.

In the case of positive security consider the existence of an integrated system of video surveillance. Negatively were focused on issues related to cheerleading, the constraints of access, especially in the days of play, and the high costs associated with security. Proposals for improving the application of the law relating to security issues and improving the component of the budget associated with security.

Education opportunities in positive terms, all components related to both existing educational visits and the training of athletes, there is a promotion for both schools as to the stakeholders. On the negative side, we highlight the poor performance of the athletes and reduced use of the space utilization of the structure. After the presentation the members proposed improvements in the promotion of new markets in the education component to the promotion of space.

How to respond to local needs, positively, there is the appreciation of the surrounding area and enhancement of various aspects of creating much like other sports. In negative terms was referenced the high investment made in a very focused structure and functional constraints do not allow the practice of all sports.

For the Economic Promotion of the local structure enables development of events, activities, businesses and jobs. The downside is appointed the high operating cost structure. It was proposed some improvement is to create a more dynamic business in the sports facility.

In relation to the Equal Access were presented as positive factors promoting: access modalities as well as the structure itself are in condition for use by persons with reduced mobility. But negatively, there is a note that not all spaces are accessible and cost of tickets is not differentiated. It was proposed the stimulation of specific protocols with entities.

Social Inclusion is considered that the sports facility promotes the development of social standards for their own sport. However it is considered as a proposal for improvements to a policy of social responsibility more effectively.

For the Traffic and Parking, the positive aspects are related to improving access in the area of influence of the structure and the high number of parking spaces existing in the football stadium. As mentioned above, negatively, congestion and noise are issues inherent to its operation. The group members proposed the improving the awareness and promotion of the use of public transport and the creation of better access.

Finally in relation to the Impact Assessment is positively verified by streamlining and economic asset value of the surrounding structure. In terms of negative evaluation is carried out by the claims, environmental impacts and the costs of existing liabilities. It was presented several proposals for improving the promotion of inspections and audits and follow-up by technological structures inherent in sports.

In the table bellow we want to demonstrate that management considering social issues creates economic benefits for stadium management. 
Table 2. Importance of the social sustainability indicators in stadium management

\begin{tabular}{|c|c|c|}
\hline Public impact & $\begin{array}{l}\text { Social Sustainability } \\
\text { Indicators }\end{array}$ & Private Impact \\
\hline $\begin{array}{ll}\text { - } & \text { public safety; } \\
\text { - } & \text { education } \\
\text { opportunity } \\
\text { - } & \text { sense of pride; } \\
\text { - } & \text { wellbeing; }\end{array}$ & Neighborhood & $\begin{array}{l}\text { - Diminishing of the } \\
\text { waste expenses; } \\
\text { - Security expenses; } \\
\text { - Negative publicity; }\end{array}$ \\
\hline $\begin{array}{ll}\text { - } & \text { Increasing public } \\
\text { participation; } \\
\text { - Opportunity of } \\
\text { social inclusion; }\end{array}$ & Education & $\begin{array}{l}\text { - Diminishing of the } \\
\text { stadium smash up } \\
\text { and waste after de } \\
\text { games; } \\
\text { - Positive publicity }\end{array}$ \\
\hline $\begin{array}{l}\text { - Work and income } \\
\text { for small business; } \\
\text { - Job creation }\end{array}$ & Economic opportunities & $\begin{array}{l}\text { - Increasing income } \\
\text { for the stadium; } \\
\text { - More customers; } \\
\text { - Better use of } \\
\text { stadium facilities; } \\
\text { - } \text { More services }\end{array}$ \\
\hline $\begin{array}{l}\text { - } \text { Bigger social } \\
\text { participation; } \\
\text { - } \begin{array}{l}\text { increasing of civic } \\
\text { activity }\end{array}\end{array}$ & Social interaction & $\begin{array}{l}\text { - New ideas for the } \\
\text { business; } \\
\text { - More awareness in } \\
\text { using stadium } \\
\text { facilities }\end{array}$ \\
\hline $\begin{array}{l}\text { - } \text { More safety; } \\
\text { - } \text { More attractive } \\
\text { stadium }\end{array}$ & $\begin{array}{l}\text { Well being of the } \\
\text { customers }\end{array}$ & $\begin{array}{l}\text { - happier customers; } \\
\text { - more customers; }\end{array}$ \\
\hline
\end{tabular}

\section{Conclusions}

All groups show that the stadium managers developed some procedures to deal with the real problems after they happened. Usually those procedures are expressed into the regulations or specific planes or have been developed after the repeated problems. We may mention here the safety evacuation plans and signalization for comfort and security of customers, and close cooperation with police force I order to try to control the football fans and traffic jam during the competitions. The big amount of waste after competitions originated the implementation of the cleaning procedure in the stadium and in surroundings after all games. In all group only one stadium was managing taking in account the creation of the economic opportunities for small business because of the necessity to increase the number of regulars not only during the games, which are not so frequent (one two and two week), but during all days. They crate the partnership agreements with local enterprises, increased number of sport facilities in order to have more practitioners in different sport activities, which crate 
the necessity of support services. All those actions happened because the local enterprises were financially involved in stadium construction.

All those activities were developed after the problems happened and none of the managerial body has some consistent program for education and for prevention the situations. They all react to problem but not prevent them.

Fist and the most important result of our work is the conclusion that every manager think that the social sustainability is important but rather secondary issue comparing with the most important economic o objective.

Here we may conclude that the including the social sustainability issues in the management practice is a very important and pertinent subject for now.

\section{Acknowledgments}

We thank the Portuguese Association Stadium and their representatives who met on 14 October 2011, and managers of stadiums Benfica, Sporting Lisbon, Porto, Leiria, Algarve and Aveiro who agreed to have us on their premises.

\section{Conflict of Interest}

"The authors declare no conflict of interest".

\section{References and Notes}

1. Assefa G. Frostell B., (2004) "Social sustainability and social acceptance in technology assessment a case study of energy Technologies, Technologies and Society (29), 63-78;

2. Colantonio, A (2009) "Social sustainability: linking research to policy and practice" . In: Sustainable development: a challenge for European research (26 - 28 May 2009 : Brussels, Belgium).

3. Colantonio, $A$ (2009) "Social sustainability: a review and critique of traditional versus emerging themes and assessment methods" . In:Second International Conference on Whole Life Urban Sustainability and its Assessment (22 - 24 April, 2009 : Loughborough, UK).

4. Lucas, S ; Silva-Afonso A.,. Ferreira, V. M (2011) "Gestão Dinâmica do Desempenho da Sustentabilidade em Estruturas Desportivas", CLME'2011, Ref. ${ }^{a}$ 121504A, Moçambique, Maputo, Setembro de 2011, ISBN 978-972-8826-23-9, 363-364;

5. Lucas, S. ; Silva-Afonso A,; . Ferreira, V. M (2010)“A sustentabilidade de grandes infra-estruturas - O caso dos estádios de futebol", CINCOS'10 - Congress of Innovation on Sustainable Constrution, 785-790, Curia, Novembro de 2010, ISBN 978-989-95978-1-5, 785-790;

6. Sachs I (1999) "Social sustainability and whole development: exploring the dimensions of sustainable development." In Egon B. and Tomas J. Editors, Sustainability and the social sciences; across disciplinary approach to integration environmental considerations into theoretical reorientation, Zed books London 
(C) 2011 by the authors; licensee MDPI, Basel, Switzerland. This article is an open access article distributed under the terms and conditions of the Creative Commons Attribution license (http://creativecommons.org/licenses/by/3.0/). 